\author{
Prof. dr. sc. Nataša Žunić Kovačević \\ Pravni fakultet Sveučilišta u Rijeci
}

\title{
PRILAGODBA HRVATSKE POREZNE UPRAVE EUROPSKOJ UNIJI
}

UDK: $336.2(497.5: 4-67$ EU)

DOI: $10.31141 /$ rrpfs.2020.57.135.195

Izvorni znanstveni rad

Primljeno: 1. studenog 2019.

\begin{abstract}
U radu se prikazuju čimbenici promjena u radu hrvatskih poreznih tijela s obzirom na to da borba protiv utaja i izbjegavanja poreza intenzivira rad na regulatornom okviru međunarodnog oporezivanja na svim razinama. Daje se povijesni presjek uređenja rada hrvatske porezne uprave u zadnja dva desetljeća, a posebno se ukazuje na globalni rat utajama poreza pa se prikazuje OECD-ov Akcijski plan - BEPS. Mjere iz tog plana na europskoj razini provedene su kroz veći broj direktiva te se izdvaja Direktiva Vijeća Europske unije protiv izbjegavanja poreza (ATAD) te posljedice implementacije u unutarnje hrvatsko zakonodavstvo. ATAD kao europski odgovor na BEPS nameće izmjene i prilagodbu poreznih tijela novim pravilima. Posebno se naglašavaju nužna prilagodba hrvatskih poreznih tijela europskim pravilima o poreznim postupcima dokazivanja izbjegavanja poreza te nužne prilagodbe i promjene područja rješavanja poreznih sporova.
\end{abstract}

Ključne riječi: porezna tijela, BEPS, ATAD, dokazivanje izbjegavanja poreza, rješavanje poreznih sporova

\section{UVODNO RAZMATRANJE}

Promjene poreznih sustava i njihova prilagodba promijenjenim društvenim okolnostima na svim razinama, nacionalnim i globalnim, nužne se i očekivane. To je posebno slučaj s onim promjenama koje su usmjerene izmjenama postojećih ili uvođenju novih poreznih oblika odnosno promjenama materijalnog poreznog prava. Takva dinamika promjena manje je prisutna kod normativnog okvira poreznog postupka odnosno u okvirima postupovnog poreznog prava. Zadnja desetljeća na globalnoj i europskoj razini obilježena su promjenama poreznog prava koje su uglavnom fiskalno motivirane pa stoga te promjene donose i stroži stav fiskusa prema poreznim obveznicima koji ne udovoljavaju poreznoj obvezi. Tako motivirane promjene u stručnoj i akademskoj zajednici predmet su prijepora s obzirom na očekivanu adekvatnost takvih mjera u ostvarenju svrhe promjena, a sve se promjene u tim prijeporima percipiraju ili isključivo kao instrumenti pojačane porezne presije prema svim poreznim obveznicima ili kao pokušaji uspostavljanja narušene porezne discipline.

U tim procesima promjena poreznih sustava često je izvan fokusa interesa svih dionika izgradnje učinkovitog oporezivanja i normativni okvir rada poreznih 
administracija. No, uz materijalno i postupovno porezno pravo, najmanje je jednako važan upravo navedeni segment, dakle rada i postupanja poreznih administracija.

\section{OD KONTINUITETA I STABILNOG PRAVNOG UREĐENJA RADA HRVATSKE POREZNE UPRAVE DO UČESTALIH I VELIKIH IZMJENA: POVIJESNI PRESJEK NORMATIVNOG OKVIRA POREZNIH TIJELA}

Zakon o poreznoj upravi iz 2001. predstavljao je stabilan normativni okvir postupanja poreznih tijela puno desetljeće. ${ }^{1}$ Do donošenja novog zakona, ukupno svega četiri izmjene zakona nisu bitno zadirale i mijenjale postupanje poreznih tijela pa je odnos s poreznim obveznicima imao u tom razdoblju brojna obilježja dobrih praksi.

Novi Zakon o poreznoj upravi iz 2012. godine kojim se bitno mijenja ustrojstvo rada hrvatske porezne administracije donio je izazove $u$ praksi ${ }^{2}$ te je $u$ tim okolnostima nakon jedne izmjene zakona, dakle vrlo brzo nakon svega jedne godine od donošenja tog zakonskog okvira, stupio na snagu novi, zakon iz 2013. godine. ${ }^{3}$

Tim je zakonskim uređenjem ${ }^{4}$ započet postupak reorganizacije porezne uprave kroz uvođenje funkcionalnog pristupa u svim poslovnim procesima $\mathrm{i} u$ radu poreznih tijela. Razdoblje primjene i rada nakon početno provedene reorganizacije ukazalo je da se u određenim područjima predviđena učinkovitost nije ostvarila. Provedeno okrupnjavanje područnih ureda i ispostava porezne uprave uzrokovalo je probleme u obavljanju poslovnih procesa. Problemi su se najvećim dijelom odrazili kroz nemogućnost komunikacije kako između samih službenika tako i između službenika i njima neposredno nadređenih službenika. Razjedinjene nadzorne funkcije kroz horizontalni pristup te nadležnost postupaka nadzora koji je bio uređen kroz više ustrojstvenih jedinica Ministarstva financija, u manje od dvije godine primjene, nisu se pokazale kao dobro organizacijsko rješenje. Uređeno praćenje obveznika kroz različite pristupe, što je značilo samim time i pokretanje međusobno nepovezanih postupaka, dodatno su otežali provedbu poreznih nadzora. Sve je to, posebno u dijelu provedbe nadzornih aktivnosti koje provodi porezna administracija, ukazalo na potrebu ustrojavanja jedinstvenog tijela ili ustrojsvene jedinice nadležne za suzbijanje poreznih prijevara kao i odvajanje navedenih funkcija od klasičnih postupaka poreznog nadzora.

Zakon o poreznoj upravi ${ }^{5}$ iz 2016. godine obilježen je potrebom mijenjanja gore navedenih poteškoća nastalih iz uređenja rada poreznih tijela u 2013. godini, ali posebno zahtjevima prilagodbe hrvatske porezne administracije europskim i

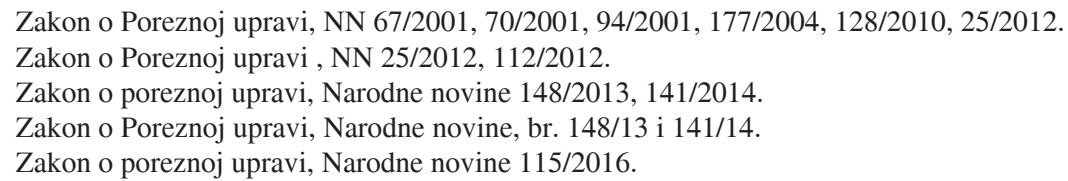


globalnim standardima. Iz prijedloga zakona jasno proizlaze prioriteti u njezinu radu koji u svom pretežitom dijelu predstavljaju usklađivanje s europskim zahtjevima. Razvoj strategija i poslova suzbijanja poreznih prijevara kroz razvijeni sustav upravljanja rizicima dio su očekivanih izazova. Dodatno, digitalno gospodarstvo traži i digitalnu poreznu administraciju. Digitalno gospodarstvo jedan je od čimbenika i globalne erozije porezne osnovice što postavlja velike zahtjeve u odnosu na porezna tijela u oporezivanju. ${ }^{6}$ Digitalizacija poreznih tijela jedan je od očekivanih trendova koji su neizbježni. ${ }^{7}$ Tako se dosadašnja opterećenost poslovnih procesa porezne uprave brojnim administrativnim postupcima uvelike rješava novim automatiziranim postupcima te postizanjem elektroničke dvosmjerne komunikacije između porezne uprave i poreznih obveznika - digitalna porezna uprava donosi i nove izazove koje će trebati svladati. ${ }^{8}$ Promjene u paradigmi odnosa poreznih vlasti i poreznih obveznika ${ }^{9}$ nametnule su nove zakonske odredbe u propisu o poreznoj administraciji kojima se želi naglasiti neophodna savjetodavna uloga porezne uprave te izgraditi partnerski odnos s poreznim obveznicima. Promjene u funkcionalnoj i teritorijalnoj organizaciji prateći su element navedenih sadržajnih promjena. Sve te promjene nametnule su i brojne provedbene propise pa tako važeći zakon ima pet temeljnih provedbenih i podzakonskih propisa. Među njima se posebno izdvaja Uredba o unutarnjem ustrojstvu Ministarstva financija ${ }^{10}$ gdje se izmjenama iz 2019. godine može primijetiti i naglašena potreba određenog i većeg broja službenika i namještenika koji trebaju raditi na dodatnim i promijenjenim poslovima poreznih tijela kako ih uređuje važeći zakonski okvir.

\section{HRVATSKA POREZNA ADMINISTRACIJA I PRILAGODBA ZA BEPS I ATAD}

Hrvatska porezna uprava je, uz druge europske porezne administracije, doduše i one izvan tog kruga, suočena s ozbiljnim promjenama društvenog okvira, pri čemu je spremnost hvatanja u koštac s istima različita od države do države. Jedan od većih izazova leži u borbi protiv erozije porezne osnovice. Snažni globalizacijski procesi donijeli su i brojne mogućnosti raznim oblicima poreznih planiranja koji uključuju u najvećoj mjeri izbjegavanje poreznog opterećenja i obveza. Međunarodni i

6 Lipniewicz, R., 2017., ,Tax administration and risk management in the digital age“, Information System in Management, Vol. 6 (1), 26-37, prema Vuković, Marija, Towards the digitalization of tax administration, str. 1.

7 IMPACT OF DIGITALISATION ON THE TRANSFORMATION OF TAX ADMINISTRATIONS WWW.IOTA-TAX.ORG.

8 IMF/OECD (2019.), 2019 Progress Report on Tax Certainty, Paris. www.oecd.org/tax/tax-policy/ g20-report-on-tax-certainty.htm (10. IX. 2019.).

9 Bogata je stručna i znanstvena literatura o navedenoj promjeni: OECD (2013.), Co-operative Compliance: A Framework: From Enhanced Relationship to Co-operative Compliance, OECD Publishing, Paris, https://doi.org/10.1787/9789264200852-en.; Bronžewska, Katarzyna, Cooperative Compliance: A New Approach to Managing Taxpayer Relations, IBFD, 2016.

10 Uredba o unutarnjem ustrojstvu Ministarstva financija, Narodne novine 54/2017., 26/2018., 66/2019. i 79/2019. 
inozemni elementi poreznih odnosa često dovode do teškoća u radu poreznih tijela u oporezivanju što dodatno otvara daljnje mogućnosti poreznih planiranja. Iako izgrađena europska, ali i međunarodna administrativna suradnja poreznih tijela različitih država te mreža međunarodnih poreznih ugovora doprinose suzbijanju takvih neželjenih pojava, neizbježna je promjena postojećih odnosno uvođenje novih međunarodnih standarda kao temeljnih načela međunarodnoga poreznoga prava. Borba protiv praksi izbjegavanja plaćanja poreza te izgradnja općeg i zajedničkog normativnog sustava s takvim ciljem pretvorili su se u jedan od temeljnih ciljeva Europske unije i njezinih država članica.

Cilj svih rasprava i ideja vodi k ostvarivanju temeljnih načela poreznoga prava među kojima se ističe načelo pravednosti oporezivanja. Ipak, taj cilj dio je globalne platforme i napora Organizacije za ekonomsku suradnju i razvoj (eng. Organisation for Economic Co-operation and Development, dalje u tekstu: OECD). Izbjegavanje plaćanja poreza zadnjih je nekoliko desetljeća globalno pitanje koje traži globalan odgovor. Tako je 2013. godine OECD donio Akcijski plan o eroziji porezne osnovice i alokaciji profita (eng. Base Erosion and Profit Shifting, dalje u tekstu: BEPS $)^{11}$ kojim se predlažu i uvode gotovo radikalne promjene u borbe protiv erozije porezne osnovice i poreznog planiranja. BEPS je projekt OECD-a i grupe G20 koji je započeo 2011. godine, a odnosi se na strategije za izbjegavanje dvostrukog oporezivanja kojima se istražuju propusti i neusklađenosti u poreznim propisima sa svrhom preusmjeravanja dobiti u jurisdikcije s niskim ili bez poreznih stopa, što za posljedicu ima neplaćanje poreza na dobit ili plaćanje poreza na dobit u vrlo malim iznosima. Neke procjene ukazuju na svjetske godišnje gubitke od odnosno 100 do 240 milijardi dolara godišnje. ${ }^{12}$ Akcijski plan BEPS nastao je uz podršku ministara financija država članica G20, što njegov utjecaj na formiranje poreznih politika na svim razinama čini neupitnim.

Akcijski plan BEPS sastoji se od petnaest mjera pri čemu je za određene mjere određen rok primjene od dvanaest do osamnaest mjeseci od donošenja Akcijskog plana BEPS, za neke je određen rok od dvije godine, dok je za treću skupinu mjera određen rok dulji od dvije godine.

Prva mjera Akcijskog plana BEPS odnosi se na područje digitalne ekonomije. ${ }^{13}$ Hibridne neusklađenosti (engl. hybrib mismatches) odnosno neutralizacija učinaka tako osmišljenih aranžmana obuhvaćeni su drugom mjerom BEPS-

11 OECD (2013.), Action Plan on Base Erosion and Profit Shifting, OECD Publishing. Dostupno na: http://dx.doi.org/10.1787/9789264202719-en (17. IX. 2019.).

12 Vidi detaljnije na http://www.oecd.org/tax/treaties/multilateral-instrument-BEPS-tax-treatyinformation-brochure.pdf. (15. IX. 2019.).

13 Ovom se mjerom nastoji potaknuti analiza raznih poslovnih modela cjelovitim pristupom, uzimajući u obzir izravno i neizravno oporezivanje. Svrha ove mjere jest pronalazak funkcionalnih rješenja za probleme koji se u praksi javljaju prilikom primjenjivanja međunarodnih poreznih pravila. Rasprava obuhvaća pitanja određivanja mjesta nastanka dodane vrijednosti te osiguranja učinkovitog prikupljanja PDV-a kod digitalne prodaje. Mjera naglašava potrebu za većom suradnjom država kako bi se osiguralo učinkovito oporezivanje dobiti multinacionalnih kompanija. Ističe se važnost formiranja novih međunarodnih poreznih pravila. Primjer dobre implementacije novih međunarodnih poreznih pravila u nacionalno porezno zakonodavstvo može biti Francuska, odlučna uvesti dodatni porez digitalnim kompanijama ukoliko se ne postigne sporazum na razini Europske unije o tom pitanju. 
a. ${ }^{14}$ Prije stupanja na snagu ATAD-a, donesene su izmjene i dopune koje se tiču hibridnih neusklađenosti ${ }^{15}$ što predstavlja obuhvatniju regulaciju. Pravila o kontroliranim inozemnim društvima (eng. Controlled foreign corporation rules, dalje u tekstu CFC) sačinjavaju treću mjeru. ${ }^{16}$ Peta se mjera sastoji u učinkovitijem suprotstavljanju štetnim poreznim praksama. Kao prioritet određuje se rad na poboljšanju transparentnosti. Sprečavanje zlouporabe ugovora razrađuje se u šestoj mjeri ${ }^{17}$ te se ističe potreba redefiniranja koncepta stalne poslovne jedinice (engl. permanent establishment - PE). O tome je riječ i u sedmoj mjeri te o potrebi sprečavanja zlouporabe statusa SPJ radi izbjegavanja plaćanja poreza kao i pitanjima pripisivanja dobiti. Osma, deveta i deseta mjera odnose se na transferne cijene. Druge se mjere odnose na metodologiju prikupljanja i analizu podataka o BEPS-u te na radnje za suzbijanje neželjenih pojava poput obveze poreznih obveznika da objave zaključene sporazume o transfernim cijenama, ispitivanje dokumentacije o transfernim cijenama, pronalaženje mehanizama radi učinkovitijeg rješavanja sporova te razvoj multilateralnog instrumenta koji omogućuje implementaciju mjera. Tako je sklopljena Multilateralna konvencija o provedbi mjera povezanih s ugovorima o izbjegavanju dvostrukog oporezivanja (engl. Multilateral Convention to Implement Tax Treaty Related Measures to Prevent BEPS, dalje u tekstu: MLI), na snazi od 1. srpnja 2018. godine, a s ciljem provođenja navedenih mjera i neophodnih izmjena bilateralnih poreznih ugovora. ${ }^{18}$

Europska unija je u tim okolnostima i prije donošenja BEPS-a poduzimala brojne aktivnosti, poput prijedloga iz 2013., pa potom prijedloga iz 2016. godine

14 Poteškoće koje se u ovom kontekstu spominju: dvostruko neoporezivanje, dvostruki odbitak te dugoročno odgađanje plaćanja poreza.

15 Direktiva Vijeća (EU) 2017/952 od 29. svibnja 2017. o izmjeni Direktive (EU) 2016/1164 u pogledu hibridnih neusklađenosti s trećim zemljama, SL L 144, 7. VI. 2017.

16 Porezno priznati odbitak zbog plaćanja kamata i drugih financijskih plaćanja dovodi do dvostrukog neoporezivanja: npr. kreditiranje povezanog društva visokim kamatnim stopama, odnosno kada se isplaćene kamate odbijaju od oporezive dobiti, a takva su društva često smještena u ,porezna utočišta“ čime se omogućuje da se prihod od kamata oporezuje povoljnije ili se čak ne oporezuje. Mjera se odnosi na sprečavanje erozije porezne osnovice odbitkom kamata i drugih financijskih plaćanja predviđanjem pravila koja ograničavaju prekomjerno korištenje troška kamate s ciljem smanjivanja porezne osnovice te posljedično dužnog poreza. Vidi, L. Hillmann, R. Hoehl, „Interest Limitation Rules: At a Crossroads between National Sovereignty and Harmonization“, European Taxation, vol. 58, br. 4, 2018., str. 140-145.

17 Mjera se razrađuje s ciljem neutralizacije učinaka hibridnih neusklađenosti. Vidi o zabrani zloupotrebe ugovora u Sertić, A., „Ograničenje pogodnosti iz ugovora o izbjegavanju dvostrukog oporezivanja u kontekstu Akcijskog plana BEPS“, Porezni vjesnik, vol. 24., br. 9. (2015.), str. 119123. Ova mjera znači razvoj modela te preporuke uređivanja domaćih pravnih pravila o ograničavanju pogodnosti koje mogu proizlaziti iz ugovora o izbjegavanju dvostrukog oporezivanja. Cilj sklapanja takvih ugovora zasigurno nije postići dvostruko neoporezivanje, već izgraditi i razvijati pravna pravila te komunikacijske kanale što će za cilj imati oporezivanje prema ugovorom utvrđenim načelima i to načelima međunarodnog poreznog prava.

18 Multilateralna konvencija o provedbi mjera povezanih s ugovorima o izbjegavanju dvostrukog oporezivanja u svrhu sprečavanja smanjenja porezne osnovice i preusmjeravanja dobiti (Multilateralni instrument ili MLI) prekretnica je u međunarodnom poreznom pravu jer omogućuje svim zainteresiranim jurisdikcijama da ažuriraju svoje ugovore o izbjegavanju dvostrukog oporezivanja s odredbama koje odražavaju nove standarde dogovorene na međunarodnoj razini. Vidi i: Sadiq, K., Sawyer, A., McCredie, B., „Jurisdictional responses to base erosion and profit shifting: a study of 19 key domestic tax systems“, eJournal of Tax Research, vol. 16, br. 3. (2019.), str. 8-10. 
o direktivi o zajedničkoj konsolidiranoj poreznoj osnovici poreza na dobit (engl. Common Consolidated Corporate Tax Base; dalje u tekstu: CCCTB).${ }^{19}$ Odgovorila je na BEPS brzo kroz direktivu protiv izbjegavanja plaćanja poreza: Direktiva Vijeća (EU) 2016/1164 od 12. srpnja 2016. godine o utvrđivanju pravila protiv praksi izbjegavanja poreza kojima se izravno utječe na funkcioniranje unutarnjeg tržišsta (engl. Anti Tax Avoidance Directive; dalje u tekstu: ATAD). ${ }^{20}$

\section{a. Ukratko o ATAD-u}

ATAD je europski odgovor na BEPS s ciljem osiguravanja pravednog i učinkovitog oporezivanja te prikupljanja poreznih prihoda, a temeljem novih međunarodnih pravila. Time je potvrđen značaj provođenja mjera BEPS-a na razini država članica radi ostvarenja pravednog i učinkovitog, ali koordiniranog oporezivanja na razini EU-a. Takav europski odgovor bilo je moguće postići jer se radi o instrumentu kojim se uklanjaju prepreke funkcioniranja unutarnjeg tržišta.

ATAD propisuje de minimis zaštitu odnosno ne isključuje primjenu odredbi višeg stupnja zaštite domaćih ili nacionalnih poreznih osnovica poreza na dobit. Drugim riječima, radi se o direktivi minimalne harmonizacije jer države članice mogu primjenjivati više standarde od onih predviđenih direktivom.

ATAD uvodi četiri specifična pravila protiv izbjegavanja plaćanja poreza (engl. Specific Anti-Tax Avoidance Rules; dalje u tekstu: SAARs) i jedno opće pravilo za suzbijanje zlouporabe (engl. General Anti-Tax Avoidance Rule; dalje u tekstu: GAAR).

Države članice obvezne su uskladiti nacionalno zakonodavstvo s ATAD-om do 31. prosinca 2018. godine, dok se nove odredbe trebaju primjenjivati od 1. siječnja 2019. godine, uz izuzetak za usklađivanje nacionalnih zakonodavstava s ATADom gdje je isti rok 31. prosinca 2019. godine, a odnosi se na pravila ATAD-a o izlaznom oporezivanju. Ipak, za neka pravila je propisano - za države članice koje imaju jednako učinkovita ciljana nacionalna pravila o ograničavanju kamata na snazi na dan 8. kolovoza 2016. godine mogu najkasnije do 1. siječnja 2024. godine primjenjivati ta pravila ili do isteka prve fiskalne godine tj. prvog poreznog razdoblja nakon datuma objave sporazuma među članovima OECD-a o minimalnom standardu u pogledu četvrte mjere Akcijskog plana BEPS.

\section{i. Prilagodba i zahtjevi za porezna tijela država članica u primjeni ATAD-a $i$ pravila protiv izbjegavanja plaćanja poreza}

ATAD uvodi pravila kojima se potvrđuje predana europska borba protiv izbjegavanja plaćanja poreza uz očuvanje poreznog suvereniteta i fiskalne stabilnosti

19 Prijedlog Direktive Vijeća o zajedničkoj konsolidiranoj osnovici poreza na dobit (CCCTB), (COM (2011.) 121).

20 Direktiva Vijeća (EU) 2016/1164 od 12. srpnja 2016. o utvrđivanju pravila protiv praksi izbjegavanja poreza kojima se izravno utječe na funkcioniranje unutarnjeg tržišta, SL L 193, 19. VII. 2016. 
država članica. Normativni okvir s tim ciljem treba biti provediv od poreznih tijela i dovoljno jasan i precizan za porezne obveznike. Osim općeg pravila za suzbijanje zlouporabe koje se primjenjuje supsidijarno tj. u svim slučajevima kada se specifična pravila ne mogu primijeniti jer ne reguliraju određene situacije, ATAD uređuje četiri posebna ili specifična pravila protiv izbjegavanja plaćanja poreza: pravilo o ograničavanju kamata, pravilo o izlaznom oporezivanju, pravilo o kontroliranim inozemnim društvima te pravilo koje se tiče hibridnih neusklađenosti.

Izlazno oporezivanje (engl. exit taxation) posebno je pravilo protiv izbjegavanja plaćanja poreza kojim se omogućuje državi članici koju napušta porezna osnovica tj. iz koje se ona „seli““ oporezivati gospodarsku vrijednost kapitalne dobiti nastale na njezinu teritoriju iako takva dobit još nije ostvarena u trenutku kad ta porezna osnovica napušta navedenu poreznu jurisdikciju.

Pravilo o kontroliranim inozemnim društvima (dalje: pravilo CFC) posebno je ili specifično pravilo protiv izbjegavanja plaćanja poreza u slučaju kada u porezno relevantnim transakcijama sudjeluju povezana društva različite europske rezidentnosti. Hibridne neusklađenosti predmet su četvrtog posebnog ili specifičnog pravila protiv izbjegavanja plaćanja poreza sa svrhom neutralizacije učinaka hibridnih instrumenata i subjekata na porezne sustave država članica.

GAAR ili opće pravilo izbjegavanja plaćanja poreza jedna je od važnijih novina donesenih na europskoj razini. GAAR ima za cilj izbjegavanje poreznih praksi zlouporaba koje nisu predmetom posebnih ili specifičnih pravila, odnosno supsidijarno se primjenjuje u svim onim slučajevima kada neprihvatljiva porezna praksa nije uređena SAARs-om. ATAD uređuje da se GAAR ima primjenjivati na neautentične aranžmane, ali u kontekstu primjene te odredbe javljaju se pojmovi poput „,neautentičnosti“, „glavne svrhe“, „,valjanih komercijalnih razloga“ i „gospodarske stvarnosti“ što predstavlja svjevrsni standard sadržaja i značenja koje određuje Sud Unije. ${ }^{21}$ Test GAAR-a sastoji se od tri kumulativna testa. To su fiktivnost (engl. artificiality), motiv (engl. motive) te poništavanje cilja i svrhe primjenjivog poreznog prava (engl. defeat of object and purpose of corporate tax law). ${ }^{22}$ Ako su sva tri testa ispunjena ili ostvarena, riječ je o neautentičnom aranžmanu te se porezna obveza utvrđuje sukladno nacionalnom poreznom pravu. Test GAAR-a mora se provoditi pojedinačno za svaki aranžman. Provjera je li neki aranžman autentičan ili nije utvrđuje se kao questio facti. ${ }^{23}$

ATAD ne propisuje pravila vezana uz teret dokaza koje bi bilo od značaja za primjenu GAAR-a. Neke dvojbe iz prakse o tome tko snosi teret dokazivanja u postupku riješene su kroz sudsku praksu Suda EU-a: ,propis države članice na temelju kojeg se (...) za priznavanje izuzeća od poreza po odbitku nalaže dokazivanje neporeznih razloga za strukturu vlasničkog lanca, bez obveze upravnih tijela da predoče dovoljno indicija za umjetnu konstrukciju bez uporišta u gospodarskoj stvarnosti koja je usmjerena na ostvarivanje poreznih pogodnosti - neprihvatljiv

\footnotetext{
21 Helminem, M., EU Tax Law - Direct Taxation, IBFD, Amsterdam, 2018., str. 270-274.

22 Wattel, P., J., Terra, B., J., M., op. cit. u bilj. 33, str. 269-271.

23 Ibid, str. 271.
} 
je“ ${ }^{24}$ Automatsko prebacivanje tereta dokaza nije dozvoljeno, jednako kao ni automatsko isključenje mogućnosti dokazivanja suprotnog..$^{25}$

Porezna tijela u primjeni ATAD-a i navedenih pravila trebaju dokazati postojanje rizika od porezne evazije ili zlouporabe, i to u svakom pojedinačnom slučaju. Dodatno, iz prakse Suda EU-a jasno je da opće pravilo za suzbijanje zlouporaba koje bi a priori isključivalo određene kategorije operacija ne bi bilo u skladu s načelom proporcionalnosti. ${ }^{26}$ Dakle, nije dopuštena generalna presumpcija zlouporabe i izbjegavanja plaćanja poreza niti se može opravdati fiskalnim razlozima. ${ }^{27}$

Dakle, BEPS i ATAD stavljaju pred porezna tijela posebne zahtjeve u primjeni navedenih odredbi. ${ }^{28}$ Porezna tijela moraju omogućiti poreznom obvezniku u svako doba podnositi dokaze u prilog postojanja komercijalnih i drugih neporeznih razloga provođenja određene transakcije bez pretjeranih administrativnih ograničenja i troškova. ${ }^{29}$

Teret dokaza u poreznim stvarima dijele porezni obveznici i porezna tijela, no subjektivni test koji se odnosi na motiv poreznog obveznika kao i objektivni test koji znači poništavanje svrhe i cilja primjenjivog poreznog prava uvijek moraju biti zadovoljeni i dokazani od poreznog tijela u svakom slučaju posebno. ${ }^{30}$

\section{ii. Izazovi za porezna tijela: implementacija ATAD-a i hrvatski pravni okvir}

Implementacija ATAD-a započela je 2016. godine kroz dva hrvatska porezna propisa, mijenjana pod utjecajem ATAD-a čime su pred hrvatsku poreznu administraciju stavljeni brojni izazovi jednoobrazne europske primjene navedenih pravila same direktive. ${ }^{31}$

Opći porezni zakon (dalje u tekstu: OPZ) ${ }^{32}$ do 2016. godine sadržavao je pravila koja su po svrsi veoma slična GAAR-u. Tako OPZ uređuje da se porezne činjenice moraju utvrđivati prema njihovoj gospodarskoj biti. Dodatno, porezno tijelo utvrđuje poreznu obvezu prema posebnom propisu koji uređuje određenu vrstu poreza ako je prihod, dohodak, dobit ili druga procjenjiva korist ostvarena bez pravne osnove. Tako je uvedeno načelo gospodarskog pristupa činjenicama bitnima za oporezivanje u hrvatski porezni sustav od prvog donošenja tog općeg poreznog

\footnotetext{
24 Presuda Equiom, C-6/16, EU:C:2017:641, para. 61.

25 Wattel, P., J., Terra, B., J., M., op. cit. u bilj. 33., str. 273-274. 102.

${ }^{26}$ Mišljenje nezavisnog odvjetnika Jána Mazáka o presudi Elisa, C-451/05, EU:C:2007:594, para.

27 Vidjeti presudu: Judgment of 10 November 2011, Foggia, EU:C:2011:718, para. 37., posebno vidjeti Judgment of 10 November 2011, Foggia, EU:C:2011:718, para. 37.

28 Wattel, P., J., Terra, B., J., M., op. cit. u bilj. 33, str. 274.

29 Presuda Test Claimants, C-524/04, EU:C:2007:161, para. 82.

30 Žunić Kovačević, Nataša; Gadžo, Stjepan, „Tax-related Risks of Mergers and Acquisitions... “, Zbornik Pravnog fakulteta Sveučilišta u Rijeci, vol. 39, br. 4 (Posebni broj), 1731-1749 (2018.).

31 Prikaz hrvatskog zakonodavstva koje se odnosi na sprečavanje izbjegavanja plaćanja poreza, vidi u: Žunić Kovačević, Nataša, Croatia, in Dourado, A. P., (ed.), Tax Avoidance Revisited in the EU BEPS Context, IBFD, 2017.

32 Opći porezni zakon, Narodne novine, br. 147/08, 18/11, 78/12, 136/12, 73/13 i 26/15.
} 
propisa. Time se jasno daje i uređuje prednost gospodarske metode u primjeni i tumačenju poreznih propisa. ${ }^{33}$ Drugim riječima, porezna su tijela dužna promatrati sadržaj određenih operacija, što prevladava nad formalnim elementima porezno relevantnih transakcija i poslova. Dodatno, OPZ uređuje pojavu prividnih pravnih poslova pa je, sukladno članku 11. OPZ-a, osnova za utvrđivanje porezne obveze prikriveni pravni posao u slučaju da se tim prividnim pravnim poslom prikriva neki drugi pravni posao. ${ }^{34}$ Takve norme daju pravo poreznim tijelima, nakon što je isto dokazalo, kvalificirati određenu transakciju prividnom. Iako je postojanje ovih pravila u hrvatskom poreznom zakonodavstvu i prije donošenja ATAD-a otvorilo pitanje potrebe uvođenja GAAR-a, ipak GAAR osnažuje porezno zakonodavstvo i omogućuje ujednačenu praksu koja se razvija kao europska praksa primjene GAAR-a ${ }^{35}$ Korisna praksa Suda EU-a može puno učiniti u izgradnji i održavanju pravednijeg poreznog sustava u kojem je zajamčena pravna sigurnost poreznog obveznika. Tako bi iz te prakse valjalo uputiti na promjenu praksi hrvatskih poreznih tijela u kojoj porezni obveznik mora dokazivati da se porezno relevantna transakcija ili posao provode radi valjanih gospodarskih razloga te mora otkloniti pretpostavku kako njegov posao ili transakcija za glavni cilj ili jedan od glavnih ciljeva ima utaju ili izbjegavanje plaćanja poreza. Drugim riječima, u dosadašnjoj je praksi poreznih tijela u primjeni europskog zakonodavstva teret dokazivanja u potpunosti bio na poreznom obvezniku pa je takvim postupanjima stvorena opća pretpostavka porezne evazije, a što je protivno pravu EU-a. ${ }^{36}$

Drugi hrvatski poreznopravni propis koji predstavlja implementaciju ATAD-a jest Zakon o porezu na dobit (dalje u tekstu: ZPdob). ${ }^{37}$ ZPdob se mijenja već 2016. godine s ciljem usklađivanja hrvatskog poreznog okvira s europskim, posebno kroz članak 5.a Zakona o izmjeni i dopuni Zakona o porezu na dobit (dalje u tekstu: ZIDZPdob) ${ }^{38}$ Upravo ta odredba predstavlja uvođenje GAAR-a u hrvatsko porezno zakonodavstvo. Time je uređeno da porezni obveznik neće moći koristiti prava propisana ZPdobom koja se osobito odnose na umanjenje porezne osnovice, izuzeća, oslobađanja od plaćanja poreza i poreza po odbitku ili umanjenje porezne obveze za aranžmane ili niz aranžmana ako se utvrdi da ih je osnovao radi ostvarivanja, kao glavne svrhe ili jedne od glavnih svrha, navedenih pogodnosti. Jednako kao i ATAD, propisuje se da aranžmani ili niz aranžmana moraju biti neautentični za primjenu navedene odredbe. Dodatno se pojašnjava da aranžman predstavlja bilo koju poslovnu transakciju, aktivnost, shemu, sporazum, obvezu ili događaj

33 Rihter, A., „Načela poreznog/upravnog postupka“, Porezni vjesnik, vol. 25, br. 1 (2016.), str. 44.

34 Rihter, A., op. cit. u bilj. 86., str. 44.

35 Vidi Čičin-Šain, N., „Analyse comparée des dispositifs de lutte contre l'évasion fiscale en droit fiscal croate et français“, Le cas de l’impôt sur les sociétés, L.G.D.J., 2017., str. 87-92; Gadžo, S., Klemenčić, I., ,Time to stop avoiding the tax avoidance issue in Croatia? A proposal based on recent developments in the European Union“", Financial theory and practice 38(3), 2014., str. 282.

36 Primjena Općeg poreznog zakona, Narodne novine, br. 115/16, 106/18; vidi predmet Foggia (f.n. br.26) i drugi.

37 Zakon o porezu na dobit, Narodne novine, br. 177/04, 90/05, 57/06, 146/08, 80/10, 22/12, 148/13, 143/14, 50/16, 115/16 i 106/18.

38 Zakon o izmjeni i dopuni Zakona o porezu na dobit, Narodne novine, br. 50/16. 
te da se može sastojati od više mjera ili dijelova te se navodi da se neautentičnim aranžmanom ili aranžmanima smatraju aranžman ili aranžmani u mjeri u kojoj nisu osnovani radi valjanih komercijalnih razloga koji odražavaju gospodarsku stvarnost odnosno ako su osnovani radi utaje ili izbjegavanja poreza. Dakle, time je uveden GAAR u hrvatsko porezno zakonodavstvo pa porezna tijela u primjeni tih pravila imaju na raspolaganju razvijenu europsku praksu, upravnu i sudsku, kako bi ispravno postupala. ${ }^{39}$

Godine 2018. hrvatski se ZPdob dodatno usklađuje s ATAD-om u pogledu pravila o ograničenju kamata te pravila CFC-a čime je hrvatskom zakonodavcu preostalo još samo implementirati pravila ATAD-a o izlaznom oporezivanju te o hibridnim neusklađenostima. ${ }^{40}$ Kako je riječ o dijelovima poreznih sustava koji su poznati brojnim europskim državama, to hrvatska porezna tijela imaju mogućnost korištenja europskih dobrih praksi. Sve navedeno ukazuje na postojanje posebnih izazova koji stoje u narednom razdoblju pred hrvatskim poreznim tijelima, posebno u pogledu neophodnog informiranja poreznih obveznika i svih dionika oporezivanja s opisanim noveliranim pravilima i normativnim okvirom. To nameće nužnost osnaženja i organizacijskih i ljudskih resursa te njihovih kapaciteta.

Posebno zahtjevnim za porezna tijela čini se izazov koji predstavljaju mjere 14 iz plana BEPS-a o minimalnim standardima poboljšanja rješavanja sporova, što uključuje mehanizme temeljene na sporazumima i same administrativne prakse odnosno administrativna ili upravna tijela koja rješavaju žalbe poreznih obveznika.

\section{b. Prilagodba hrvatske porezne uprave minimalnim standardima upravnog rješavanja poreznih sporova}

Provedba Akcijskog plana BEPS zahtijeva intenzivne legislativne procese na svim razinama vlasti, posebno na poreznoj vlasti. Kako je riječ o uvođenju novih standarda koji pretpostavljaju neku vrstu pravne tradicije i iskustva u primjeni od ranije poznatih i sličnih nacionalnih instituta i standarda, gdje su hrvatska iskustva skromna, jasno je da će napori hrvatske porezne uprave biti tim veći. Sve navedene novine u legislativnom poreznom okviru nameću neophodno jačanje položaja poreznih obveznika i zaštitu njihovih prava. Žalbeni postupci u upravnom postupku moraju biti učinkoviti i dio su standarda koji hrvatska upravna i porezna tijela moraju postići. Promjene u radu hrvatskih poreznih tijela u području učinkovitog rješavanja poreznih sporova jesu očekivane i nužne što proizlazi iz dosadašnjih pokazatelja rada žalbenog tijela u poreznim stvarima. ${ }^{41}$

39 Vidi detaljnije, Bolander J., Graff Nielsen, J., Denmark, in Meussen G., (ed.), The Burden of Proof in Tax Law, IBFD, 2013., str. 90-98. Id r.

40 Zakon o izmjeni i dopuni Zakona o porezu na dobit, Narodne novine, br. 106/18.

41 Vidi detaljnije o žalbenim postupcima u poreznim stvarima, Žunić Kovačević, Nataša, „Upravnosudska kontrola u poreznim stvarima“, Zbornik radova Pravnog fakulteta u Splitu, god. 53, 1/2016., str. 283. 
Aktualniji primjeri učinkovitosti rješavanja sporova pred drugostupanjskim upravnim tijelima pokazuju da je riječ o kontinuitetu nezadovoljavajuće učinkovitosti rješavanja poreznih sporova. Tako je u 2016. žalbeno tijelo u poreznim stvarima zaprimilo 8112 žalbi od kojih je odbijeno čak $86 \%$ ili 7003 žalbe. U 2017. je od 5754 žalbe odbijeno njih $60 \%$ ili 3536 dok su nakon godine u kojoj je došlo do većih izmjena poreznih propisa ${ }^{42}$ dakle u 2018. godini, bile čak 17.042 žalbe od čega je njih 12.156 ili više od $70 \%$ odbijeno.

Dodatno treba primijetiti kako je za donošenje drugostupanjskih poreznih rješenja bilo potrebno, u prosjeku, čak dvije do četiri godine.

Zanimljivim se čini, naizgled propust u pisanju, uređenje žalbenog postupka kroz odredbe OPZ-a gdje se navodi: „Žalba se podnosi nadležnom drugostupanjskom poreznom tijelu..."43 te se dodatno pod naslovom dijela OPZ-a „Tijelo nadležno za rješavanje o žalbi“ u članku 183. uređuje: „O žalbi protiv poreznog akta koji je donijelo prvostupanjsko porezno tijelo odlučuje nadležno drugostupanjsko porezno tijelo određeno zakonom“. Naime, Zakon o poreznoj upravi uređuje ,,(1) Za rješavanje u upravnim stvarima u prvom stupnju nadležne su unutarnje ustrojstvene jedinice Porezne uprave prema njihovu djelokrugu. (2) Drugostupanjski upravni postupak vodi nadležna ustrojstvena jedinica za drugostupanjski upravni postupak Ministarstva financija." ${ }^{* 44}$

Uredba o unutarnjem ustrojstvu Ministarstva financija detaljnije uređuje stvarnu nadležnost takve ustrojstvene jedinice za drugostupanjski upravni postupak, naziva „Samostalni sektor za drugostupanjski upravni postupak“. ${ }^{45}$ Iz samog se naziva posebno izdvaja posebna oznaka samostalnosti za koju valja pretpostaviti da se odnosi na neovisnost i nevezanost uz „nadzirano“ “ili prvostupanjsko tijelo. Tako je u članku 36. navedene Uredbe uređeno da „Samostalni sektor za drugostupanjski upravni postupak je unutarnja ustrojstvena jedinica Ministarstva koja rješava o žalbama protiv upravnih akata Porezne uprave, Carinske uprave i upravnih akata upravnih tijela županija i velikih gradova propisanih posebnim zakonima i rješava o žalbama protiv upravnih akata unutarnjih ustrojstvenih jedinica Ministarstva; rješava povodom žalbi protiv rješenja u postupku predstečajne nagodbe; provodi postupak povodom izvanrednih pravnih lijekova; daje odgovore na tužbe povodom pokrenutih upravnih sporova i zastupa Ministarstvo pred upravnim sudovima povodom pokrenutih upravnih sporova protiv upravnih akata iz djelokruga Samostalnog sektora za drugostupanjski upravni postupak; postupa po podnescima u neupravnim predmetima; surađuje u pripremi nacrta prijedloga zakona i međunarodnih ugovora iz područja poreza i carina te u pripremi stručnih uputa radi jedinstvenog postupanja u upravnom postupku; prati primjenu poreznih i carinskih propisa te inicira njihovu izmjenu; sustavno prati međunarodne ugovore sklopljene u području poreza i carina;

${ }^{42}$ Vidi više o učincima zakonskih promjena, Rogić-Lugarić, Tereza, Čičin-Šain, Nevia, ,Alternativno rješavanje sporova u poreznom pravu: utopija ili rješenje?“", Zbornik PFZ, 64, (3), 2014., str. 348 i dr.

43 OPZ, članak 181. Stavak 1.

${ }^{44}$ Zakon o poreznoj upravi (2016.), članak 12.

45 Uredba o unutarnjem ustrojstvu Ministarstva financija, Narodne novine broj 54/2017., 26/2018., 66/2019. i 79/2019. 
prati europske smjernice u postupcima oporezivanja i carinjenja, prati i analizira sudsku praksu Europskog suda; obavlja i druge poslove iz svoga djelokruga“. U istoj se odredbi uređuje funkcionalno ustrojstvo samostalnog sektora za drugostupanjski upravni postupak, u kojem se ustrojavaju tri službe: Služba za drugostupanjski porezni postupak i zastupanje, Služba za drugostupanjski postupak u predmetima carinskog i trošarinskog nadzora, ovrhu i zastupanje i Služba za drugostupanjski postupak u poreznim nadzorima i zastupanje.

Služba za drugostupanjski porezni postupak i zastupanje provodi drugostupanjski postupak i donosi rješenja povodom žalbi protiv rješenja i zaključaka donesenih u predmetima oporezivanja dohotka, dobiti, poreza na dodanu vrijednost, obveznih doprinosa, poreza na promet nekretnina, lokalnih poreza i prekograničnog oporezivanja; provodi postupak povodom izvanrednih pravnih lijekova; priprema stručne podloge za donošenje drugostupanjskih upravnih akata; priprema odgovore na tužbe u upravnom sporu; obavlja poslove zastupanja pred nadležnim upravnim sudom; donosi rješenja u izvršenju sudskih odluka; prati primjenu poreznih propisa te inicira njihovu izmjenu i postupa po podnescima u neupravnim predmetima; obavlja i druge poslove iz svoga djelokruga. U Službi za drugostupanjski porezni postupak i zastupanje ustrojena su 3 posebna odjela: Odjel za poreze i doprinose, Odjel za porez na promet nekretnina te Odjel za lokalne poreze i prekogranično oporezivanje.

Iz navedenoga se zaključuje kako je žalbeno tijelo u poreznim stvarima ustrojstvena jedinica nadležnog Ministarstva koja u svom nazivu naglašava neovisnost i samostalnost, jasno upućujući da ne bi trebalo biti riječi o poreznom tijelu odnosno o dijelu upravne organizacije koje je dio prvostupanjskog poreznog tijela. Doduše i ovakav ustroj opravdano izaziva pozornost i sumnju u samostalnost i neovisnost u odnosu na porezno tijelo. Sve to potvrđuje i prikazana praksa postupanja istog tijela, amplius supra.

Budući da akcijski plan BEPS i Europska unija postavljaju jasan zahtjev izgradnje učinkovitog rješavanja poreznih sporova, na upravnoj i sudskoj razini, to je moguće zaključiti da je riječ o prilici za uspješnu prilagodbu hrvatskog poreznog prava europskom pravu i standardima. Prilika da hrvatska porezna tijela budu inicijator legislativnog odgovora na te zahtjeve jedinstvena je mogućnost za pokušati dosegnuti razinu europskih poreznih administracija.

Jamstvo zakonitosti postupanja poreznih tijela, kako onih u prvom stupnju, tako i drugostupanjskog tijela, nalazi se svakako u upravnom sporu te na upravnim sudovima. Uz ranije otvoreno pitanje neučinkovitosti drugostupanjskog upravnog tijela kao dijela sustava pravne zaštite u poreznim stvarima može se primijetiti svojevrstan pozitivan trend $u$ kontekstu učinkovitosti rješavanja hrvatskih poreznih sporova pred upravnim sudovima. ${ }^{46}$

46 Vidi podatke za razdoblje od 2012. godine do konca 2015. godine: Žunić Kovačević, „Upravnosudska kontrola u poreznim stvarima“, str. 285. 
Tako je na Upravnom sudu u Osijeku u 2016. godini bilo 18,03 \% poreznih predmeta u odnosu na sve zaprimljene predmete, u 2017. godini $23,07 \%$ dok je u 2018. godini taj udio iznosio $18,72 \%$. Prosječno trajanje poreznih sporova u promatranom je razdoblju iznosilo 4,1 mjeseci. U tom vremenu, dakle od 2016. godine do 2019. godine, bilo je 56,96 \% odluka u kojima je presudom odbijen tužbeni zahtjev.

Rješavanje poreznih predmeta na Upravnom sudu u Rijeci prosječno je trajalo u 2016. godini 11,4 mjeseca, u 2017. godini 9,9 te u 2018. godini svega 5,8 mjeseci. U 2016. godini, od ukupno 466 financijsko-pravna predmeta, njih $46 \%$ ili 243 predmeta završilo je s odbijenim tužbenim zahtjevom, dok je 2017. godine od ukupno 384 financijsko-pravna predmeta $52 \%$ ili 216 predmeta završilo s odbijenim tužbenim zahtjevom. U 2018. godini bilo je ukupno 429 financijsko-pravnih predmeta od kojih je $48 \%$ odnosno 207 predmeta završilo s odbijenim tužbenim zahtjevom.

Na Upravnom sudu u Splitu 2016. godine bila su riješena 433 porezna predmeta, a njihovo je rješavanje trajalo u prosjeku 5 mjeseci. Broj riješenih poreznih predmeta u 2017. i 2018. godini smanjen je na 238 i 221, dok je primijećeno nešto dulje trajanje postupka pa je u 2017. godini prosječno iznosilo 8,5 mjeseci, a u 2018. godini jednu godinu i dva mjeseca.

Na Upravnom sudu u Zagrebu u 2016. godini bilo je 10,6\% poreznih predmeta u odnosu na sve zaprimljene predmete, u 2017. godini 8,4\% dok je u 2018. godini taj udio iznosio $11,7 \%$. Prosječno su porezni sporovi u 2016. godini trajali 2 godine i 5 mjeseci, u 2017. godini jednu godinu i pet mjeseci, a 2018. dvije godine. U tom vremenu, dakle od 2016. godine do početka 2019., bilo je 41,96 \% odluka u kojima je presudom odbijen tužbeni zahtjev. ${ }^{47}$

Kako se navodi u literaturi ${ }^{48}$ o praksi hrvatskih poreznih i žalbenih tijela, priljev poreznih predmeta na žalbena tijela osjetno je veći nakon izmjena i intervencija u zakonske propise te tada posljedično raste broj uloženih žalbi te stagnira broj riješenih žalbi. U tom smislu, gore prikazana praksa drugostupanjskog žalbenog tijela isto potvrđuje. No, istodobno možemo primijetiti kako noviji podaci govore o tome da u istim okolnostima ne raste broj ili udio neriješenih tužbi, a primjetno je i da se skraćuje trajanje postupaka pred upravnim sudovima. Navedeno upućuje na pozitivne promjene sudskog rješavanja poreznih sporova, poglavito odnoseći se na prvostupanjsko porezno sudovanje.

Standardi rješavanja poreznih sporova na komparativnoj razini ne mogu biti predmetom prikaza u ovom radu, no jedan pokazatelj trendova na europskoj razini

47 Svi podaci iz sudova dostavljeni su autoru, no s obzirom na način prikaza i metodologiju koja je korištena, nije se moglo prikazati po istim indikatorima recentno postupanje sudova u poreznim stvarima. Ipak, podaci upućuju na skraćivanje trajanja postupaka pred prvostupanjskim sudovima. Podaci Visokog upravnog suda nisu bili dostupni autoru.

48 Rogić-Lugarić, Čičin-Šain, loc. cit. 
vidi se iz Direktive o mehanizmima rješavanja poreznih sporova ${ }^{49}$ koja ima za cilj učinkovito rješavanje europskih poreznih sporova. Hrvatska je implementirala tekst direktive donošenjem Zakona o mehanizmima rješavanja poreznih sporova u Europskoj uniji. ${ }^{50} \mathrm{U}$ radnim se dokumentima Hrvatskog sabora navodi cilj direktive i samoga zakona koji leži u potrebi i nužnosti osiguranja učinkovitog i djelotvornog rješavanja sporova i to u slučajevima dvostrukog oporezivanja uz potpuno uklanjanje dvostrukog oporezivanja. ${ }^{51}$ Posebno je naglasak na nužnosti poboljšanja postojećih mehanizama s ciljem stvaranja razumnog vremenskog okvira za postupak uz ujednačeno i šire područje primjene u Europskoj uniji te na povećanju učinkovitosti i sigurnosti u pogledu provedbe završne odluke. Za učinkovito poboljšanje rješavanja sporova između država članica Unije potrebna je ujednačena i usklađena provedba pravila o rješavanju sporova. Pri tome ta nužnost dosljednog i vremenski razumnog trajanja rješavanja sporova proizlazi i nastaje u kontekstu globalne borbe protiv utaja i izbjegavanja plaćanja poreza. Tako je u samom zakonu predviđeno tradicionalno ili klasično, ali i alternativno rješavanje poreznih sporova. Takvi, novi ili alternativni mehanizmi rješavanja poreznih sporova predstavljaju novu tendenciju u rješavanju sporova, a sve upućuje na nužnost prilagodbe poreznih tijela koja sudjeluju u tim sporovima te na prilagodbu i drugih tijela koja rješavaju porezne sporove na upravnoj, ali i na sudskoj razini. ${ }^{52}$

\section{UMJESTO ZAKLJUČKA}

Borba protiv utaja i izbjegavanja poreza u zadnjem je desetljeću intenzivirala rad na regulatornom okviru međunarodnog oporezivanja na svim razinama. Na široj, globalnoj razini takav okvir nastaoje u formi OECD-ova Akcijskog plana BEPS. Mjere iz tog plana na europskoj razini provedene su kroz veći broj direktiva pa su i recentne

49 Direktiva Vijeća Europske unije 2017/1852 od 10. listopada 2017. o mehanizmima rješavanja poreznih sporova u Europskoj uniji, SL L 265, 14. X. 2017. Porezni obveznici koji vode sporove, a koji proizlaze iz bilateralnih poreznih sporazuma ili konvencija kojima se predviđa uklanjanje dvostrukog oporezivanja, mogu pokrenuti postupak međusobnog sporazumijevanja prema kojem države članice moraju riješiti spor mirnim putem u roku od dvije godine. Ako na kraju dvogodišnjeg razdoblja ne dođe do rješenja spora, porezni obveznik može zatražiti osnivanje savjetodavnog povjerenstva koje će donijeti mišljenje. To savjetodavno povjerenstvo sastoji se od tri neovisna člana i predstavnika relevantnih nadležnih tijela te u roku od šest mjeseci mora dostaviti mišljenje koje države članice moraju provesti, osim ako pristanu na drugo rješenje u roku od šest mjeseci nakon donesenog mišljenja. Ako se odluka ne provede, porezni obveznik koji je prihvatio konačnu odluku i odrekao se svojeg prava na domaće pravne lijekove u roku od 60 dana od obavijesti može tražiti izvršenje pred nacionalnim sudovima. Države članice obvezne su obavijestiti porezne obveznike i objaviti konačnu odluku ili njezin sažetak.

50 Zakon o mehanizmima rješavanja poreznih sporova u Europskoj uniji, Narodne novine broj 98/2019.

51 Prijedlog zakona o mehanizmima rješavanja poreznih sporova u Europskoj uniji, dostupno na http://edoc.sabor.hr/Views/AktView.aspx?type=HTML\&id=2024029 (15. X. 2019.)

52 Vidi detaljnije sve brojniju hrvatsku literaturu o alternativnom rješavanju poreznih sporova: Maganić, Aleksandra, Dika, Mihajlo, „Mogućnost rješavanja upravnih stvari arbitražom“, Zbornik radova Novosti u upravnom pravu $i$ upravnosudskoj praksi, Visoki upravni sud Republike Hrvatske, Organizator, Zagreb, 2018., str. 1-34. Rogić Lugarić, Čičin-Šain, loc. cit.; Žunić Kovačević, loc. cit.; Maganić, A., „Granice arbitrabilnosti u rješavanju upravnih stvari“, Zakonitost, broj 1, 2019., i dr. 
zakonodavne intervencije u hrvatski porezni sustav nastale kao implementacija europskih direktiva. To se odnosi i na Direktivu Vijeća EU protiv izbjegavanja poreza (ATAD), većinu čijih je odredaba Republika Hrvatska implementirala u unutarnje zakonodavstvo. ATAD je europski odgovor na BEPS s ciljem osiguravanja pravednog i učinkovitog oporezivanja i prikupljanja poreznih prihoda temeljem novih međunarodnih pravila o minimalnim zajedničkim standardima oporezivanja. Dinamika promjena na globalnoj i europskoj razini koje se odnose na oporezivanje nameću neophodne promjene i prilagodbu poreznih administracija. Posebni izazovi za hrvatska porezna tijela leže u primjeni međunarodnih i europskih noveliranih pravila i standarda oporezivanja, od kojih su posebno izdvojene nužne prilagodbe hrvatskih poreznih tijela u primjeni normativnog okvira u postupcima dokazivanja izbjegavanja poreza te u području rješavanja poreznih sporova.

\section{ADJUSTING CROATIAN TAXATION ADMINISTRATION TO THE EUROPEAN UNION}

This paper shows the factors of change in the work of Croatian taxation bodies given that combatting taxation evasion and tax avoidance intensifies work on the regulatory framework of international taxation at all levels. An historical cross-sectional overview of the regulation of the work of the Croatian taxation office over the last two decades, showing in particular the global taxation evasion war in OECD's Action Plan - BEPS. Measures from that plan at a European level have been implemented through a large number of directives pointing out the European Council Directive against Tax Avoidance (ATED) and the consequences of implementation within Croatian legislation. ATAD as a European answer to BEPS imposes changes and adjustments to taxation bodies by new rules. Necessary adjustment of Croatian taxation bodies to European rules on taxation procedures for proving taxation evasion and necessary adjustments and changes in areas of resolving taxation disputes are particularly pointed out.

Key words: taxation bodies, BEPS, ATAD, proving tax evasion, resolving taxation disputes 